\title{
Factors Influencing Osmotic Fragility of Mycoplasma
}

\author{
By S. RAZIN \\ Department of Clinical Microbiology, Hebrew University, Hadassah \\ Medical School, Jerusalem, Israel
}

(Received 7 May 1964)

\begin{abstract}
SUMMARY
Osmotic lysis of Mycoplasma organisms was found to depend on the temperature of incubation. The organisms were practically resistant to osmotic shock at $0^{\circ}$, but lysed rapidly at $37^{\circ}$. Their sensitivity to lysis also depended on the $\mathrm{pH}$ value of the suspending medium, being lowest at $\mathrm{pH}$ values near neutrality. Divalent and polyvalent cations, in concentrations as low as $10^{-5} \mathrm{M}$, protected mycoplasmas from osmotic lysis. The parasitic Mycoplasma strains showed various degrees of osmotic fragility, Mycoplasma gallisepticum being the least fragile. All the parasitic strains tested were, however, more resistant to osmotic lysis than the saprophytic Mycoplasma laidlaroii. The possibility that osmotic lysis of mycoplasmas involves autolytic processes was tested and is discussed.
\end{abstract}

\section{INTRODUCTION}

Mycoplasma organisms are limited by a thin membrane resembling the plasma membrane of bacteria, and are completely devoid of cell walls (Razin, 1963a). In spite of the absence of cell wall, mycoplasmas were found to be much more resistant to osmotic lysis than bacterial protoplasts and spheroplasts (Razin \& Argaman, 1963). Further work showed that various Mycoplasma strains differed in osmotic fragility and that the saprophytic Mycoplasma laidlawii strains had a high degree of osmotic fragility when harvested at the logarithmic phase of growth (Razin, $1963 b$ ). To elucidate the mechanism of osmotic lysis of mycoplasmas, a study of the factors which influence osmotic fragility was undertaken.

\section{METHODS}

Organisms. Mycoplasma mycoides var. mycoides (PG 1), M. mycoides var. capri (PG3), M. agalactiae (PG 2), M. neurolyticum (PG 28) and $M$. gallisepticum (PG 31) were obtained from Dr D. G. ff. Edward (The Wellcome Research Laboratories, Beckenham, Kent). A strain of $\boldsymbol{M}$. gallisepticum named (R) was provided by Mrs Ruth Bernstein (Faculty of Agriculture, The Hebrew University, Rehovoth, Israel). Strain $\mathbf{s} 6$ of $\boldsymbol{M}$. gallisepticum was obtained from Dr H. E. Adler (School of Veterinary Medicine, University of California, Davis, U.S.A.). Mycoplasma laidlawii (oral strain) was isolated in our laboratory from the human oral cavity. This strain was serologically related to $M$. laidlawii strain A.

Suspensions of organisms. The organisms were grown in a modified Edward medium (Razin, $1963 b$ ) containing $1 \%(v / v)$ Difco PPLO serum fraction. Growth was done in $500 \mathrm{ml}$. volumes distributed in 11 . Roux flasks. The flasks were incubated 
in inclined positions to improve aeration. The organisms were harvested while the optical density of cultures was still increasing, usually after incubation for 24-48 hr at $37^{\circ}$. The organisms were sedimented by centrifugation at $16,000 \mathrm{~g}$ for $5 \mathrm{~min}$., washed twice in $0.25 \mathrm{M}-\mathrm{NaCl}$ solution and resuspended in the same solution.

Preparation of protoplasts. Protoplasts of Micrococcus lysodeikticus were prepared by lysozyme treatment, as described previously (Razin \& Argaman, 1963) and suspended in a $\mathbf{M}-\mathrm{NaCl}$ solution.

Examination of lysis. Test tubes contained $4 \mathrm{ml}$. of serial twofold dilutions of a $0.25 \mathrm{M}-\mathrm{NaCl}$ solution for testing the lysis of mycoplasmas, and of a $\mathrm{M}-\mathrm{NaCl}$ solution for testing the lysis of protoplasts. The tubes were placed in a $37^{\circ}$ water bath and each received $0.1 \mathrm{ml}$. of organism suspension. The number of viable particles in Mycoplasma suspensions was determined after $\mathbf{3 0} \mathrm{min}$. incubation according to Butler \& Knight (1960). Simultaneously, the extinction of suspensions at $500 \mathrm{~m} \mu$ was determined in a Unicam SP500 spectrophotometer. The suspensions were then centrifuged at $20,000 \mathrm{~g}$ for $10 \mathrm{~min}$., and the extinction of the clear supernatant fluids measured at $260 \mathrm{~m} \mu$. For testing the effect of temperature on osmotic lysis, extinction measurements were done in a Unicam SP 500 spectrophotometer equipped with a 'constant-temperature cell housing'.

Breakdown of cell membranes. Cell membranes of Mycoplasma laidlawii were prepared by osmotic shock of the organisms. Saline-washed packed organisms (1-2 g. wet weight) were suspended in de-ionized water (about $300 \mathrm{ml}$.), incubated at room temperature for $15 \mathrm{~min}$. and then centrifuged at $16,000 \mathrm{~g}$ for $5 \mathrm{~min}$. in the cold. The sediment, consisting mainly of unbroken organisms, was discarded and the supernatant fluid centrifuged at $34,000 \mathrm{~g}$ for $40 \mathrm{~min}$. at $4^{\circ}$. Electron microscopy showed that this sediment consisted of membranes; no unbroken organisms were observed. The sedimented membranes were resuspended in ice-cold 0.01 M-tris buffer ( $\mathrm{pH} \mathrm{8 \cdot 0}$ ) containing $0.01 \mathrm{M}-\mathrm{NaCl}$. Proteolytic activity in membrane suspensions was tested by incubating $4 \mathrm{ml}$. samples of suspension at $37^{\circ}$ for various periods of time. Extinction at $500 \mathrm{~m} \mu$ of suspensions was measured at the end of the incubation period, and the membranes were sedimented by centrifugation at $34,000 \mathrm{~g}$ for $40 \mathrm{~min}$. in the cold. The supernatant fluids were separated, concentrated by evaporation to $\mathbf{0 . 5} \mathrm{ml}$. volumes and their amino acid content analysed quantitatively by paper chromatography (Giri, Radhakrishnan \& Vaidyanathan, 1952; Razin \& Cohen, 1963). The coloured spots which appeared on the chromatogram after spraying with ninhydrin were cut off and eluted with $75 \%(\mathrm{v} / \mathrm{v})$ ethanol in water containing $0.005 \%(\mathrm{w} / \mathrm{v}) \mathrm{CuSO}_{4} \cdot 5 \mathrm{H}_{2} \mathrm{O}$. The colour intensity was determined spectrophotometrically at $540 \mathrm{~m} \mu$.

\section{RESULTS}

\section{Effect of temperature on osmotic lysis}

Lysis of Mycoplasma laidlawii by osmotic shock was temperature-dependent, and was not instantaneous; the time required for the completion of lysis depended on the incubation temperature (Fig. 1). Results obtained by the viable count technique confirmed those obtained by extinction measurements. The mycoplasmas were only slightly damaged by osmotic shock at $0^{\circ}$ (Table 1). The dependence of osmotic lysis on temperature and incubation time was found also with $\boldsymbol{M}$. mycoides var. capri and $M$. neurolyticum. The standard technique subsequently adopted for 
testing osmotic lysis of mycoplasmas accordingly included incubation of suspensions in the hyptonic solutions at $37^{\circ}$ for $30 \mathrm{~min}$. Protoplasts of Micrococcus lysodeikticus, tested for comparison, lysed almost instantly in hypotonic $\mathrm{NaCl}$ solutions, the lytic process being even more pronounced at $0^{\circ}$ than $18^{\circ}$ (Fig. 2).

\section{Resistance of heated Mycoplasma organisms to osmotic lysis}

The degree of osmotic fragility decreased proportionally to the decrease in the number of viable organisms on heating Mycoplasma suspensions (Fig. 3). Heatkilled mycoplasmas were thus shown to be resistant to osmotic lysis while protoplasts of Micrococcus lysodeikticus heated to the same temperatures remained sensitive to osmotic lysis.

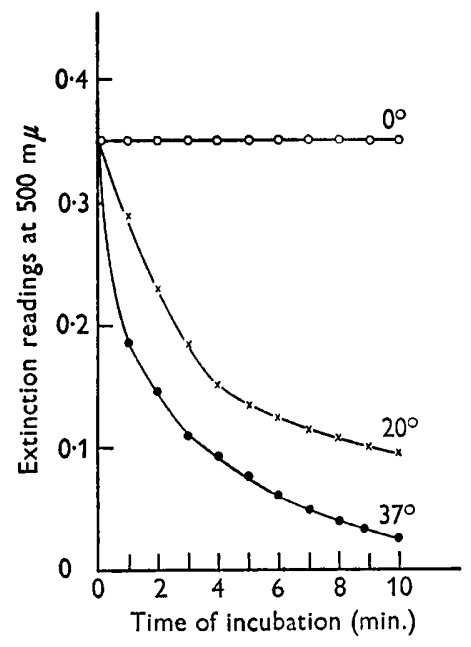

Fig. 1

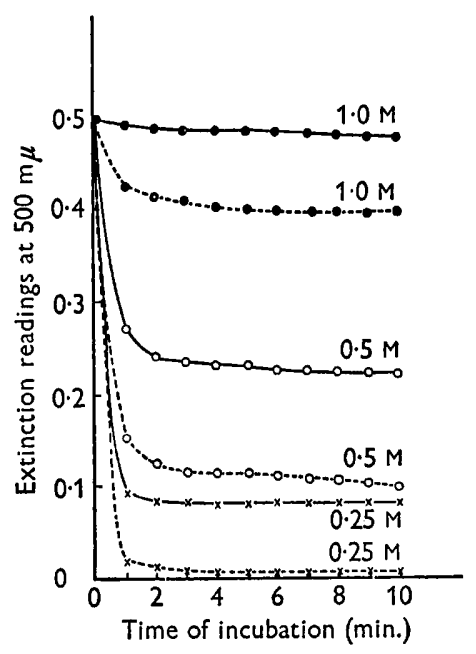

Fig. 2

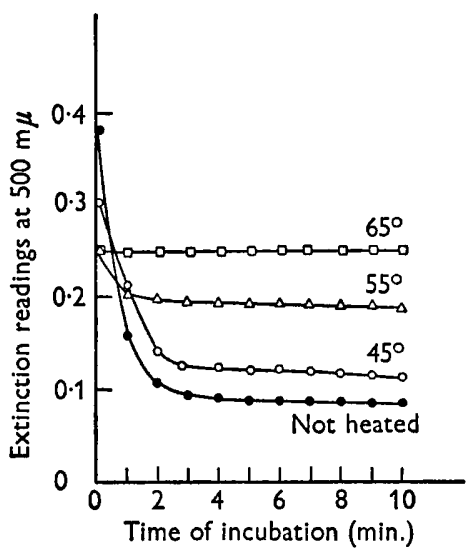

Fig. 3

Fig. 1. Osmotic lysis of Mycoplasma laidlawii at various temperatures of incubation. Test tubes containing $4 \mathrm{ml}$. de-ionized water were incubated at the temperatures indicated in figure. Each test tube received $0.1 \mathrm{ml}$. of a washed suspension of organisms in $0 \cdot 25 \mathrm{M}-\mathrm{NaCl}$ and the extinction was measured at $1 \mathrm{~min}$. intervals.

Fig. 2. Osmotic lysis of Micrococcus lysodeikticus protoplasts at various temperatures of incubation. Test tubes containing $4 \mathrm{ml}$. of various $\mathrm{NaCl}$ solutions (concentration of $\mathrm{NaCl}$ indicated in figure) received $\mathbf{0 . 1} \mathrm{ml}$. of suspension of washed protoplasts in $\mathrm{M}-\mathrm{NaCl}$. --- , Suspensions incubated at $0^{\circ} ;-$, suspensions incubated at $18^{\circ}$.

Fig. 3. Osmotic lysis of Mycoplasma laidlawii organisms heated at various temperatures. Washed suspensions in $0.25 \mathrm{M}-\mathrm{NaCl}$ were heated for $10 \mathrm{~min}$. at the temperature indicated in figure. Number of viable particles/ml. of unheated suspension, $1 \cdot 1 \times 10^{11}$; suspension heated at $45^{\circ}, 1.6 \times 10^{10}$; suspension heated at $55^{\circ}, 5.0 \times 10^{5}$; suspension heated at $65^{\circ}$, $2.5 \times 10^{4}$. The heated suspensions were tested for osmotic fragility at $37^{\circ}$, as described in Fig. 1 .

\section{Effect of $p H$ value on osmotic lysis}

Sensitivity of Mycoplasma laidlawii to osmotic lysis varied with the $\mathrm{pH}$ value of the suspending medium. Sensitivity was lowest at values between $\mathrm{pH} \mathbf{7 \cdot 0}$ and $\mathbf{8 \cdot 0}$ (Fig. 4). The mycoplasmas were somewhat more sensitive to lysis in dilute tris buffer than in phosphate buffer of the same $\mathrm{pH}$ value. The higher sensitivity of the mycoplasmas to osmotic lysis at acid or alkaline pH values was found also with M. mycoides var. capri. 
Table 1. Effect of temperature on viability of Mycoplasma laidlawii in various $\mathrm{NaCl}$ solutions

Test tubes containing $4 \mathrm{ml}$. of $\mathrm{NaCl}$ solution or de-ionized water received $0 \cdot 1 \mathrm{ml}$. of a washed suspension of organisms in $0.25 \mathrm{M}-\mathrm{NaCl}$ (final concentration of $\mathrm{NaCl}$ indicated in the table). Viable counts were made after $30 \mathrm{~min}$. of incubation.

$$
\begin{gathered}
\mathrm{NaCl} \\
\text { concentration }
\end{gathered}
$$

(M)

$0 \cdot 250$
$0 \cdot 037$
$0 \cdot 006$

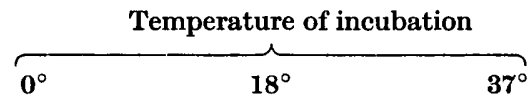

No. of viable organisms $/ \mathrm{ml}$. suspension

$\begin{array}{lll}4.4 \times 10^{9} & 4.5 \times 10^{9} & 4.5 \times 10^{9} \\ 3.6 \times 10^{9} & 2.1 \times 10^{9} & 7.0 \times 10^{8} \\ 8.8 \times 10^{8} & 1.1 \times 10^{7} & 8.4 \times 10^{5}\end{array}$

Table 2. Protection by cations of Mycoplasma laidlawii and protoplasts of Micrococcus lysodeikticus from osmotic lysis

Test tubes containing $4 \mathrm{ml}$. of neutralized solutions of the salts in de-ionized water received $0.1 \mathrm{ml}$. washed Mycoplasma suspension in $0.25 \mathrm{M}-\mathrm{NaCl}$ or washed protoplasts in $1.0 \mathrm{M}-\mathrm{NaCl}$. Extinction of suspensions measured after $30 \mathrm{~min}$. incubation at $37^{\circ}$.

\section{Organism and Salt}

Mycoplasma laidlawii

Spermine.4HCl

Spermidine phosphate

$\mathrm{UO}_{2}\left(\mathrm{NO}_{3}\right)_{2} \cdot 6 \mathrm{H}_{2} \mathrm{O}$

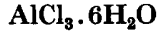

$\mathrm{Fe}_{2}\left(\mathrm{SO}_{4}\right)_{3}$

$\mathrm{FeSO}_{4} \cdot 7 \mathrm{H}_{2} \mathrm{O}$

$\mathrm{MgCl}_{2} \cdot 6 \mathrm{H}_{2} \mathrm{O}$

$\mathrm{MnCl}_{2} \cdot 4 \mathrm{H}_{2} \mathrm{O}$

$\mathrm{CaCl}_{2}$

$\mathrm{BaCl}_{2} \cdot 2 \mathrm{H}_{2} \mathrm{O}$

$\mathrm{CuCl}_{2} \cdot 2 \mathrm{H}_{2} \mathrm{O}$

$\mathrm{ZnCl}_{2}$

$\mathrm{CdCl}_{2}, 2 \frac{1}{2} \mathrm{H}_{2} \mathrm{O}$

$\mathrm{Hg}\left(\mathrm{NO}_{3}\right)_{2}$

$\mathrm{NaCl}$

$\mathrm{KCl}$

LiCl

$\mathrm{NH}_{4} \mathrm{Cl}$

Protoplasts of $\boldsymbol{M}$. lysodeikticus

Spermine.4 $\mathrm{HCl}$

$\mathrm{MgCl}_{2} \cdot 6 \mathrm{H}_{2} \mathrm{O}$

$\mathrm{MnCl}_{2} \cdot 4 \mathrm{H}_{2} \mathrm{O}$

\begin{tabular}{|c|c|c|c|c|c|}
\hline \multicolumn{6}{|c|}{ Concentration of salt $(\mathbf{M})$} \\
\hline $10^{-1}$ & $10^{-2}$ & $10^{-3}$ & $10^{-4}$ & $10^{-5}$ & $10^{-6}$ \\
\hline \multicolumn{6}{|c|}{ Extinction of suspension at $500 \mathrm{~m} \mu$} \\
\hline - & 0.42 & $0 \cdot 38$ & $0 \cdot 37$ & $\mathbf{0} \cdot \mathbf{3 7}$ & $0 \cdot 08$ \\
\hline- & 0.41 & $0 \cdot 40$ & $\mathbf{0 \cdot 3 5}$ & $\mathbf{0} \cdot \mathbf{2 0}$ & $0 \cdot 08$ \\
\hline- & 0.42 & $\mathbf{0} \cdot \mathbf{3 9}$ & $\mathbf{0 \cdot 3 8}$ & $\mathbf{0} \cdot \mathbf{3 3}$ & $\mathbf{0} \cdot \mathbf{2 3}$ \\
\hline - & $\mathbf{0} \cdot \mathbf{3 7}$ & $\mathbf{0 \cdot 3 6}$ & $\mathbf{0} \cdot \mathbf{3 6}$ & $\mathbf{0} \cdot \mathbf{3 6}$ & $\mathbf{0} \mathbf{3 0}$ \\
\hline$\ldots$ & 0.45 & 0.44 & $0 \cdot 40$ & $0 \cdot 39$ & $0 \cdot 30$ \\
\hline- & $0 \cdot 40$ & $0 \cdot 39$ & $\mathbf{0} \cdot \mathbf{3 6}$ & $\mathbf{0} \cdot \mathbf{3 4}$ & $0 \cdot 20$ \\
\hline $0 \cdot 43$ & $0 \cdot 40$ & $0 \cdot 40$ & $0 \cdot 36$ & $\mathbf{0} \cdot \mathbf{3 3}$ & $0 \cdot 20$ \\
\hline $0 \cdot 42$ & $0 \cdot 37$ & $0 \cdot 37$ & $\mathbf{0} \cdot 37$ & $0 \cdot 36$ & $0 \cdot 31$ \\
\hline $0 \cdot 47$ & $\mathbf{0} \cdot 39$ & $0 \cdot 35$ & 0.34 & $0 \cdot 18$ & 0.09 \\
\hline 0.44 & 0.41 & 0.42 & 0.42 & 0.34 & 0.22 \\
\hline 0.45 & 0.39 & 0.37 & 0.37 & $0 \cdot 36$ & $0 \cdot 17$ \\
\hline- & 0.44 & 0.40 & $0 \cdot 40$ & $0 \cdot 39$ & 0.30 \\
\hline $0 \cdot 41$ & $0 \cdot 39$ & $0 \cdot 39$ & 0.38 & $0 \cdot 35$ & $\mathbf{0} \cdot 30$ \\
\hline- & 0.42 & 0.38 & 0.38 & $0 \cdot 31$ & $0 \cdot 13$ \\
\hline $0 \cdot 43$ & 0.09 & 0.08 & 0.08 & 0.08 & 0.08 \\
\hline 0.48 & $0 \cdot 10$ & $0 \cdot 10$ & 0.09 & 0.09 & 0.09 \\
\hline 0.39 & 0.08 & 0.08 & 0.08 & 0.07 & 0.07 \\
\hline $\mathbf{0 . 3 9}$ & $0 \cdot 10$ & 0.08 & 0.08 & 0.08 & 0.08 \\
\hline 一 & 0.42 & 0.20 & $0 \cdot 16$ & 0.02 & 0.02 \\
\hline 0.27 & 0.08 & 0.08 & 0.07 & 0.02 & 0.02 \\
\hline $\mathbf{0 . 3 5}$ & $0 \cdot 18$ & 0.07 & 0.06 & 0.02 & 0.02 \\
\hline 0.04 & 0.02 & 0.02 & 0.02 & 0.02 & 0.02 \\
\hline
\end{tabular}

$\mathrm{NaCl}$

\section{Protective effect of cations}

Trivalent and divalent cations were very effective in protecting Mycoplasma laidlawii against osmotic lysis; monovalent cations were completely ineffective. A long series of trivalent and divalent cations as well as spermine and spermidine inhibited osmotic lysis at $10^{-5} \mathrm{M}$ or even lower concentrations (Table 2). Spermine prevented the death of $M$. laidlawii organisms in a highly hypotonic medium (Fig. 5). The polyamines and divalent cations afforded some protection against osmotic 
lysis of Micrococcus lysodeikticus protoplasts, but at much higher concentrations than required to protect mycoplasmas (Table 2).

\section{Osmotic lysis of parasitic Mycoplasma strains}

In earlier studies parasitic Mycoplasma strains were found to be relatively resistant to osmotic lysis (Razin, 1963b). The finding that osmotic lysis of Mycoplasma laidlawii was temperature-dependent urged us to re-examine the osmotic fragility of the parasitic strains, by using $37^{\circ}$ as the incubation temperature. In addition to measuring the extinction of suspensions viable counts were made. By these

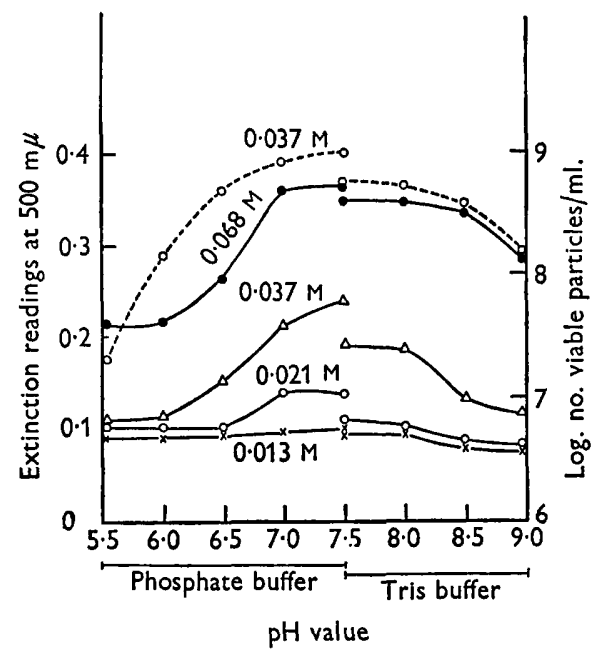

Fig. 4

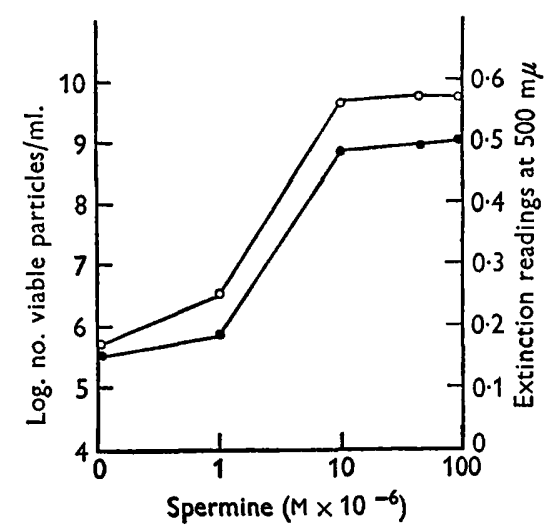

Fig. 5

Fig. 4. Osmotic lysis of Mycoplasma laidlawii at various pH values. Lysis was examined in $\mathrm{NaCl}$ solutions (concentrations indicated in figure) prepared in $0.01 \mathrm{M}$-phosphate buffer, or in $0.01 \mathrm{M}$-tris buffer. Extinction measurements $(-)$ and viable counts $(---)$ were made after incubation at $37^{\circ}$ for $30 \mathrm{~min}$.

Fig. 5. Protection by spermine against lysis and death of Mycoplasma laidlawii suspended in $0.006 \mathrm{M}-\mathrm{NaCl}$. Viable counts $(O)$ and turbidity measurements $(O)$ were made after incubation at $37^{\circ}$ for $30 \mathrm{~min}$.

techniques the parasitic strains were found to lyse and die in hypotonic solutions (Fig. 6). However, the degree of lysis of the parasitic strains rarely reached that of the saprophytic $M$. laidlawii strains. The various parasitic strains differed in osmotic fragility. Thus, all three $M$. gallisepticum strains tested were usually more resistant to osmotic lysis than the other strains of parasitic Mycoplasma. The parasitic strains frequently showed variations in osmotic fragility. Apparently one of the factors responsible for these fluctuations is the age of the culture. This had already been demonstrated for $M$. laidlawii (Razin, 1963b) and was found to be true also for M. mycoides var. capri, which was much more sensitive to osmotic lysis when harvested at the logarithmic phase of growth (Fig. 7). On testing osmotic fragility of the parasitic strains, it was noted that the number of viable $M$. neurolyticum organisms significantly decreased during washing and incubation in $0.25 \mathrm{M}-\mathrm{NaCl}$. The toxic effect of $\mathrm{NaCl}$ was less pronounced at lower temperatures. Mycoplasma laidlarvii, 
$M$. mycoides var. mycoides and $M$. gallisepticum were not significantly affected by $0 \cdot 25 \mathrm{M}-\mathrm{NaCl}$. Washing of $M$. neurolyticum in 0.4 M-sucrose + 0.01 M-phosphate buffer (pH 7.0) according to Rodwell \& Abbot (1961) was found to be preferable to washing in $0.25 \mathrm{M}-\mathrm{NaCl}$.

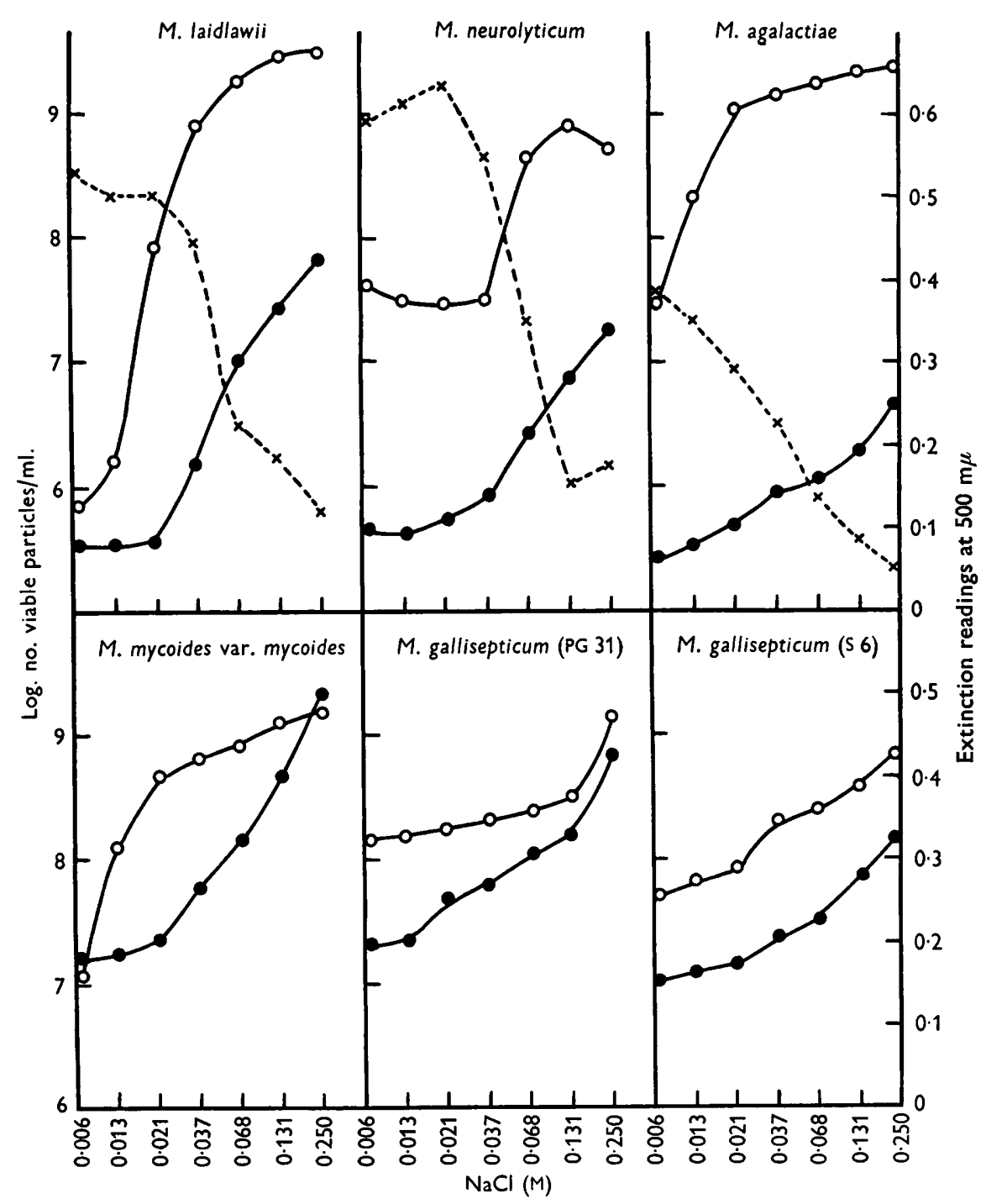

Fig. 6. Susceptibility of various Mycoplasma strains to osmotic lysis. The extent of lysis in the various $\mathrm{NaCl}$ solutions was measured after $30 \mathrm{~min}$. incubation at $37^{\circ}$. Extinction readings at $500 \mathrm{~m} \mu$ of suspensions $(O)$; extinction readings at $260 \mathrm{~m} \mu$ of the supernatant fluids of the corresponding suspensions $(x)$; number of viable particles/ml. suspension $(O)$.

\section{Breakdown of Mycoplasma laidlawii membranes}

Isolated membranes of Mycoplasma laidlawii were examined for disintegration by following the methods devised by Brown(1962). The optical extinction of membrane suspensions decreased markedly during the first $5 \mathrm{~min}$. of incubation at $37^{\circ}$, followed 
by an increase in the amount of free amino acids in the supernatant fluids of the suspensions (Fig. 8). However, electron microscopy revealed no gross morphological changes in the membranes, even after incubation at $37^{\circ}$ for $1 \mathrm{hr}$.

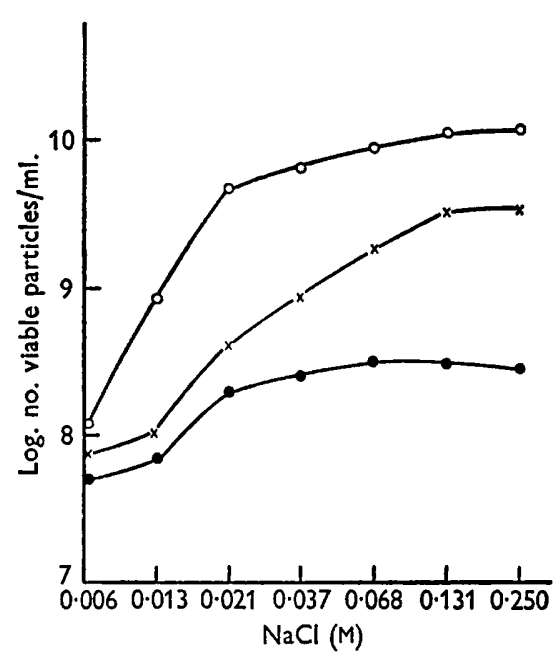

Fig. 7

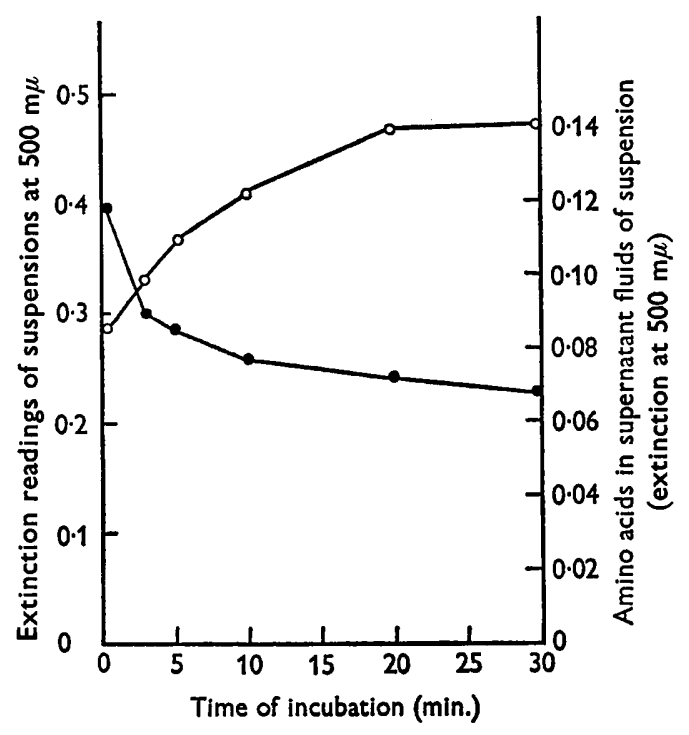

Fig. 8

Fig. 7. Death of Mycoplasma mycoides var. capri in hypotonic $\mathrm{NaCl}$ solutions. Organisms grown in Edward medium were harvested after $22 \mathrm{hr}(O), 38 \mathrm{hr}(x)$ or $66 \mathrm{hr}(O)$ incubation at $37^{\circ}$. The washed organisms were suspended in the various $\mathrm{NaCl}$ solutions and viable counts made after $30 \mathrm{~min}$. incubation at $37^{\circ}$.

Fig. 8. Proteolysis in suspensions of Mycoplasma laidlawii membranes. The membranes were incubated at $37^{\circ}$ in $0.01 \mathrm{M}-\mathrm{NaCl}$ containing $0.01 \mathrm{M}$-tris buffer ( $\mathrm{pH} \mathrm{8.0)}$. Extinction of suspensions ( $)$ and the amount of free amino acids in the supernatant fluids of centrifuged suspensions (O) were determined after various incubation times as described under Methods.

\section{DISCUSSION}

The dependence of the osmotic lysis of Mycoplasma organisms on temperature may explain the observations of Butler \& Knight (1960) that washed Mycoplasma bovigenitalium organisms rapidly died in 0.01 M-phosphate buffer at room temperature (about $20^{\circ}$ ), but survived well in the same hypotonic buffer at 2-4. Several of the parasitic Mycoplasma strains previously found to be relatively resistant to osmotic lysis at room temperature (Razin, $1963 b$ ) were lysed at $37^{\circ}$. However, even then strains of parasitic Mycoplasma in general showed a higher resistance to osmotic shock than strains of saprophytic Mycoplasma. Most resistant to osmotic lysis were $M$. gallisepticum strains. This observation might be of some interest in view of the opinion that $\boldsymbol{M}$. gallisepticum should not be regarded as Mycoplasma proper (Klieneberger-Nobel, 1963). However, electron microscopy (Ruys \& Van Iterson, 1961) and chemical analysis of organisms (Morowitz et al. 1962; Razin, Argaman \& Avigan, 1963) did not show any fundamental difference between $M$. gallisepticum and other strains of Mycoplasma. The lower osmotic fragility shown by several strains of parasitic Mycoplasma may in part be due to their being harvested at the decline phase of growth. Like saprophytic organisms (Razin, 1963b), parasitic 
Mycoplasma organisms were also found to be most sensitive to osmotic shock when harvested in the logarithmic phase of growth. Harvesting of the more exacting Mycoplasma strains at this phase was not always possible, because of their poor and sluggish growth.

Inhibition of osmotic lysis of Mycoplasma fits in well with the known protective effect of di- and multi-valent cations on osmotically fragile organisms and organelles (Tabor, Tabor \& Rosenthal, 1961). The ability of very low spermine concentrations to protect Mycoplasma organisms from lysis and death in highly hypotonic media at $37^{\circ}$ may be of use in nutritional and metabolic studies, where viability and metabolic activity of the organisms can thus be kept under the above-mentioned conditions.

The temperature dependence of the osmotic lysis of Mycoplasma, and the resistance of heated mycoplasmas to lysis, suggested that the lytic process may involve autolytic enzyme activity. Autolysis might be triggered by initial damage to the cell membrane by osmotic shock. The studies of Brown and his collaborators on the lysis of marine and extremely halophilic bacteria provide certain hints in favour of this hypothesis. The envelope of the extremely halophile Halobacterium halobium resembles that of Mycoplasma in being composed of a lipoprotein unit membrane devoid of the mucopeptide polymer (Brown \& Shorey, 1963; Brown, 1963). The envelope of a marine pseudomonad was composed of two lipoprotein membranes (Brown, Drummond \& North, 1962). The membranes of the pseudomonad, when isolated by osmotic lysis of the organisms, underwent intense autolysis of a proteolytic nature (Brown, 1961). The autolytic process, like the osmotic lysis of Mycoplasma, depended on temperature, $\mathrm{pH}$ value and ionic strength of the medium, and was inhibited by di- and multi-valent cations (Brown, 1962). Our results indicate that disintegration and proteolysis of Mycoplasma laidlawii membranes might take place on incubation at $37^{\circ}$. However, gross disintegration like that described for membranes of the marine pseudomonad (Brown et al. 1962) could not be seen in the electron microscope. Autolytic processes therefore probably play only a secondary role in the clearing of Mycoplasma suspensions after the initial osmotic shock. The studies of Edebo $(1961 a-c)$ on sonic and osmotic lysis of bacteria may provide another approach to explain the effects of incubation temperature, heat, $\mathrm{pH}$ value and polyvalent cations on osmotic lysis. According to Edebo sonic or osmotic lysis of bacteria is a two-step process; the first step involving initial structural damage to the cell envelope, and the second, the dispersion of protoplasm in the surrounding medium. All the factors which influence sonic or osmotic lysis are known to affect the transformation of the protoplasmic gel into a sol, and its dispersion in the medium.

It is a pleasure to acknowledge the expert technical assistance of $\mathbf{M r} \mathbf{M}$. Wormser. This investigation was supported in part by the Hebrew University Authority for Research and Development.

\section{REFERENCES}

Brown, A. D. (1961). The peripheral structures of Gram-negative bacteria. I. Cell wall protein and the action of a lytic enzyme system of a marine pseudomonad. Biochim. biophys. Acta, 48, 352.

Brown, A. D. (1962). The peripheral structures of Gram-negative bacteria. III. Effects of cations on proteolytic degradation of the cell envelope of a marine pseudomonad. Biochim. biophys. Acta, 62, 132. 
Brown, A. D. (1963). The peripheral structures of Gram-negative bacteria. IV. The cation-sensitive dissolution of the cell membrane of the halophilic bacterium, Halobacterium halobium. Biochim. biophys. Acta, 75, 425.

Brown, A. D., Drummond, D. G. \& North, R. J. (1962). The peripheral structures of Gram-negative bacteria. II. Membranes of bacilli and spheroplasts of a marine pseudomonad. Biochim. biophys. Acta, 58, 514.

Brown, A. D. \& Shorey, C. D. (1963). The cell envelopes of two extremely halophilic bacteria. J. cell. Biol. 18, 681 .

Butler, M. \& KNight, B. C. J. G. (1960). The survival of washed suspensions of Mycoplasma. J. gen. Microbiol. $22,470$.

Ерево, L. $(1961 a)$. Lysis of bacteria. 1. Influence of enzyme inhibitors on sonic lysis. Acta path. microbiol. scand. 52, 372.

Eрево, L. (1961 b). Lysis of bacteria. 2. Studies on the mechanisms involved in mechanical lysis. Acta path. microbiol. scand. 52, 384.

EDEBo, L. $(1961 c)$. Lysis of bacteria. 3. On the stability of protoplasts and spheroplasts in different pH-ranges. Acta path. microbiol. scand. 53, 121.

Giri, K. V., Radhakrishnan, A. N. \& Vaidyanathan, C. S. (1952). A simple paper chromatographic method for the study of transamination reactions. Nature, Lond. 170, 1025.

Klieneberger-Nobel (1963). Some current trends in the field of PPLO. Recent Progress in Microbiology. Ed. by N. E. Gibbons. Symp. int. Congr. Microbiol. 8, 504. Toronto: University Press.

Morowitz, H. J., Tourtellotte, M. E., Gulld, W. R., Castro, E., Woese, C. \& Cleverdon, R. C. (1962). The chemical composition and submicroscopic morphology of Mycoplasma gallisepticum, avian PPLO 5969. J. molec. Biol. 4, 93.

Razin, S. (1963a). Structure, composition and properties of the PPLO cell envelope. Recent Progress in Microbiology. Ed. by N. E. Gibbons. Symp. int. Congr. Microbiol. 8, 526. Toronto: University Press.

RAzIN, S. (1963b). Osmotic lysis of Mycoplasma. J. gen. Microbiol. 33, 471.

Razin, S. \& Argaman, M. (1963). Lysis of Mycoplasma, bacterial protoplasts, spheroplasts and L-forms by various agents. J. gen. Microbiol. 30, 155.

Razin, S., Argaman, M. \& Avigan, J. (1963). Chemical composition of Mycoplasma cells and membranes. J.gen. Microbiol. 33, 477 .

RAzIN, S. \& Cohen, A. (1963). Nutritional requirements and metabolism of Mycoplasma laidlawii. J. gen. Microbiol. 30, 141.

Rodwell, A. W. \& Аввот, A. (1961). The function of glycerol, cholesterol and long-chain fatty acids in the nutrition of Mycoplasma mycoides. J.gen. Microbiol. 25, 201.

RuYs, A. C. \& VAN Iterson, W. (1961). Some characteristics of pathogenic avian PPLO. Antonie van Leeuwenhoek, 27, 129.

Tabor, H., Tabor, C. W. \& Rosenthal, S. M. (1961). The biochemistry of the polyamines : spermidine and spermine. A. Rev. Biochem. 30, 579. 